Saudi Journal of Oral and Dental Research

Abbreviated Key Title: Saudi J Oral Dent Res

ISSN 2518-1300 (Print) |ISSN 2518-1297 (Online)

Scholars Middle East Publishers, Dubai, United Arab Emirates

Journal homepage: https://saudijournals.com/sjodr

Review Article

\title{
The Challenging Perception of Pediatric Dental Practice Post COVID the New Normal
}

\author{
Dr. Ummey Salma, BDS MDS (PhD) ${ }^{1 *}$, Dr. Rahul VC Tiwari, OMFS, FOGS, PhD Scholar ${ }^{2}$, Dr. Anil Managutti, Prof. \& \\ $\mathrm{HOD}^{3}$, Dr. Mahendra Azad, MDS ${ }^{4}$, Dr. Preetham Ravuri, MDS ${ }^{5}$, Dr. Sirisha Kommuri, MDS ${ }^{6}$, Dr. Heena Tiwari, BDS, \\ $\mathrm{PGDHHM}^{7}$ \\ ${ }^{1}$ Research scholar, Department of Pediatric and Preventive Dentistry, M.S. Ramaiah University of Aapplied Sciences, Banglore,
2,3 Dept of OMFS, Narsinbhai Patel Dental College and Hospital, Sankalchand Patel University, Visnagar, Gujarat India
${ }^{4}$ Director \& Cheif Consultant, Maxillofacial Surgery and Implantologist, CLOVE Dental, Hyderabad, Telanagana India
${ }^{5}$ Consultant Orthodontist \& Dentofacial Orthopeadics, Zonal head, CLOVE Dental, Visakhapatnam, Andhra Pradesh, India
${ }^{6}$ Consultant Prosthodontist, Clinic Head, CLOVE Dental Shantipuram, Akkayyepalem, Visakhapatnam, Andhra Pradesh, India
${ }^{7}$ Ex-Government Dental Surgeon, Kondagaon, Chhattisgarh, India
}

DOI: $10.36348 /$ sjodr.2020.v05i09.003

| Received: 22.08.2020 | Accepted: 30.08.2020 | Published: 03.09.2020

*Corresponding author: Dr. Ummey Salma, BDS MDS (PhD)

\section{Abstract}

The disaster of Severe Acute Respiratory Syndrome COVID-19 caused by coronavirus infection (SARS-CoV-2) has led to a global pandemic and one of the most significant challenges to the healthcare professions. The number of confirmed COVID-19 cases among healthcare workers has been increasing. Coming to Dental practices, these are the crucial points for cross-infection, hence maximum care must be taken to minimise the risk of infection to, from, or between dental care professionals and patients. Covid-19 may also spread through aerosols generated during various dental treatments, resulting in transmission between patients and dentists. Since Covid-19 cases have also been reported among children, pediatric dentists are at risk of Covid-19 infection. At the same time pediatric dentist has a major task to deal with their routine dental treatment procedures in this covid pandemic,starting with patient management till the treatment ends.

Keywords: Coronavirus, Pediatric dental practice, new normal post-COVID-19 dental practice.

Copyright @ 2020: This is an open-access article distributed under the terms of the Creative Commons Attribution license which permits unrestricted use, distribution, and reproduction in any medium for non-commercial use (NonCommercial, or CC-BY-NC) provided the original author and source are credited.

\section{INTRODUCTION}

At the start of 2020, the novel virus severe acute respiratory syndrome coronavirus 2 (SARS-CoV2) appeared, causing the coronavirus disease (COVID19). The budding virus has resulted in a global epidemic declared a Public Health Emergency of International Concern (PHEIC) by the World Health Organization (WHO) Director-General on the recommendation of the International Health Regulations (2005) Emergency Committee [1]. The transmission model of the novel coronavirus and its elevated virulence involve direct and indirect human contagiousness by proximity, potentially spreading through saliva and respiratory fluids $[2,3]$. During the pandemic, most health teams, especially in the medical field, acquired the disease during the care of infected individuals. In dentistry, there is a considerable occupational risk given the nature of procedures performed on an outpatient setting, making patient care a potential challenge in coping with this disease $[4,5]$. In this setting, dental procedures, in which a large number of droplets and aerosols, containing microorganisms from an infected individual, could be generated, are at high risk of cross infection between patients and dentists [6].This risk is even more severe in pediatric dentistry, being the majority of COVID-19 infected patients asymptomatic or mild and moderate symptomatic. This review is an attempt to discuss how the pediatric dental practioner deals with regular dental procedures in post covid situation.

\section{A New-Look Service?}

Changes are inevitable. 'Services are going to appear very different over the next few months as we adapt to the changing situation'. 'In our specialty we're talking about 'Building Back Better' so that we can return to a new normal. Post covid practice is not only challenging for treating patient, but also that the pediatric dentists use all the necessary precautions (dental consideration and infection control protocols) to avoid any viral infections to reassure the parents. The basic factors important in post covid to the new normal are 
- How post covid dental services will adapt?

- Could the practioner face the biggest changes post-COVID-19?

- To what extent will patients suffer from these changes?

\section{Doubted Parents}

'We shouldn't underestimate what a challenge lockdown may have been for the workforce. So much of our job satisfaction comes from relationships with our patients and their parents. From the past few months childrens have been delayed in treatment due to parents stress and financial crisis which has landed up in more difficult situations. Also parents are reluctant to bring their child to healthcare dental services because of anxiety about catching virus. Therefore we need to clear their doubts by giving proper counseling as well as to ensure new flexible approaches arrived after the covid situation.

\section{Use of Digital Resources}

Digital resources, Social stories have been created a positive impact on, specialty in paediatric dentistry, to help children and young people prepare to visit the dental hospital. Looking to the past and present situation scheduling of patients is performed via telephone contact or online guidance, such as using WhatsApp ${ }^{\circledR}$. The availability of online applications and resources facilitates prior contact with parents and guardians as a way of screening patients. Thus, it is possible to more accurately identify the complaint and reason for dental care, including sharing photos and images, facilitating the elaboration of the treatment plan. Caregivers should also be asked to inform the pediatric patients in advance, according to their degree of understanding, that the dental office environment will be different from the usual, without toys for distraction in the waiting room, in addition to the characterization and vestment of the professional team in order to minimize possible patient's aversion and awkwardness. A professional video record regarding the use of the Personal Protective Equipment (PPE) could be provided to the caregivers aiming the child's guidance before arriving at the dental office. This will be advantegous for forming a good repo with pediatric patient and practioner as well as in reducing the anxiety of the patient.

\section{Pre-Operative Period}

Thorough Care and measures to be taken to prevent SARS-CoV-2 transmission to children, as well as the transmission from infected children to professionals and other patients [3, 7]. Biosafety instructions can be reinforce by using alternative resources like Visual alerts (signs and posters) at the office's entrance and in strategic locations (waiting areas and elevators). Environments should be well ventilated with open windows to renew circulating air so that there will be reduction in contamination by droplets suspended in the environment and deposits on surface for long period $[8,9]$. The waiting room should have space between chairs and commonly handling objects like magazine and toys should be removed. Personal protective equipment such as a shoe protector and cap for the child and companion should be provided. The use of mouth rinses like $1 \%$ hydrogen peroxide and $0.12 \%$ chlorhexidine digluconate are used as pre-procedure mouth rinses[9] also $0.2 \%$ povidoneiodine is recommended as it might reduce the load of corona virus in saliva[10].

\section{Operative Period}

When the patient is on the dental chair, one of paediatric dentistry's first concerns is that children might be frightened by dentists dressed in full PPE'. So, designed new illustrated leaflets to help prepare families and patients in advance and preempt these anxieties. It is also suggested to avoid prolonging conversations focused on difficulties and adversities, especially related to the pandemic period [11]. In pediatric dental practice, effective infection control measures for the prevention or minimization of viral infection transmission can be implemented by a) controlling the gag or cough reflex; b) reducing aerosol/ splatter generation; c) managing contaminated air and d) improving personal protection. The gag or cough reflex may be stimulated by certain procedures, such as posterior intraoral and bite-wing radiographs and taking impressions.

Orthopantomographs or oblique lateral views may be considered instead of intraoral radiographs for screening, whereas oral mucosa in very sensitive patients may be anesthetized before taking impressions [12]. During aerosol generating procedures use of high evacuated suctions are recommended which might create a negative impact on patient while operating due to high sounds hence additional instructions should be given before starting with operating procedure.

\section{Post-Operative Period}

The postoperative period involves the patient's care and supervision after dental procedures. Parents are instructed to be more vigiliant in any changes in children after treatment. And in case observed any signs and symptoms to be informed immediately. As well as implementing teledentistry and triage protocols which provides a pragmatic approach to evaluate and record the oral health status postoperatively and hence improve the overall delivery of oral care [13]. 


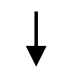
Adaptating New flexible approach

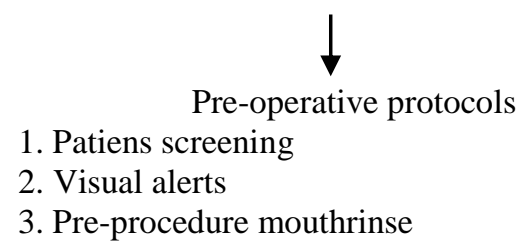
Pre-operative protocols
2. Visual alerts
3. Pre-procedure mouthrinse

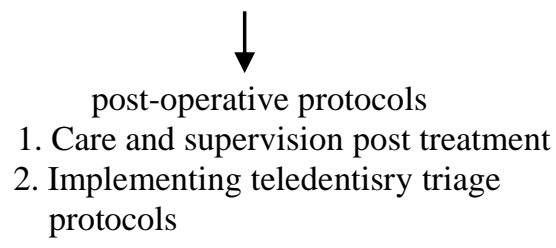
2. Anxiety management
3 . Reassuring parents

\section{Adaptation of techniques and equipments}

\begin{tabular}{|l|l|}
\hline \multicolumn{1}{|c|}{ Affected patients } & \multicolumn{1}{c|}{ Adaptation of techniques and equipments } \\
\hline All children & $\begin{array}{l}\text { - The air-water syringe must be used with care; and replace washing with a syringe with } \\
\text { saline. } \\
\text { - Preference for drying with cotton and gauze. } \\
\text { - Minimize the use of the dental spittoon, with constant saliva suction, preferably with } \\
\text { dental vacuum pump. } \\
\text { •Attention and care in the handling medications and dental materials to avoid cross- } \\
\text { infection. }\end{array}$ \\
\hline $\begin{array}{l}\text { Children who require } \\
\text { protective stabilization }\end{array}$ & $\begin{array}{l}\text { The companion must assist in patient restraint with mask and goggles. The assistance } \\
\text { aims not to overload the dental staff, since contact with body fluids such as sweat is } \\
\text { inherent to this type of approach. }\end{array}$ \\
\hline $\begin{array}{l}\text { Immunologically } \\
\text { compromised children }\end{array}$ & $\begin{array}{l}\text { They should be scheduled as the first appointment of the day, minimizing the risk of } \\
\text { exposure to the environment, with increased attention to infection control and air } \\
\text { turnover, given their increased susceptibility when infected by SARS-CoV-2, in addition } \\
\text { to having medical contact for clarifications }\end{array}$ \\
\hline $\begin{array}{l}\text { Children who require } \\
\text { urgent treatments }\end{array}$ & $\begin{array}{l}\text { Such children should have their procedures maximized, preferably aimed at the adequacy } \\
\text { of the oral environment, and avoiding recurring visits to the dental office. }\end{array}$ \\
\hline $\begin{array}{l}\text { Children with caries } \\
\text { lesions with or without } \\
\text { restorative needs }\end{array}$ & $\begin{array}{l}\text { Consider the risk of dental caries, directing strategies for the treatment of active caries } \\
\text { lesions in enamel and dentin; Use fluoride varnishes, silver diamine fluoride, pit and } \\
\text { fissure sealants, temporary and atraumatic restorations, in addition to constant } \\
\text { Reinforcement of the diet and use of fluoride toothpaste. Restorative treatment must be } \\
\text { performed by quadrants under rubber dam isolation, reducing the production of saliva, } \\
\text { aerosol and particles Contaminated by blood. If possible, choose non-aerosol-generating } \\
\text { restorative procedures. Use high-speed handpiece without water spray; and give } \\
\text { preference to manual instruments and low rotation }\end{array}$ \\
\hline
\end{tabular}

\section{CONCLUSION}

In conclusions, considering the unique work environment of dentists, which involves close patient contact and aerosol production, is formidable task for practitioner. Practicing in post covid situation will have to mark the beginning of new methods of approach and management in pediatric dentistry. The use of smart technological systems, during the pandemic period has blossomed to become the most powerful remote communication tool, which has proven to be of great help for both the patients as well as their parents.

On the other hand, the specialists in pediatric dentistry will have matured and strengthened their dedication to the practice in the post-pandemic period, not only by improving and modernizing the approach techniques, but also by proposing new models of treatment that may include the use of remote controls through special platforms, with practical guides dedicated to parents, in order to monitor and preserve the great heritage of general health, of which oral health is an important component.

\section{REFERENCES}

1. World Health Organization. (2020). https://www.who.int/news-room/detai 1/30-012020-state ment-on-the-secon d-meeti ng-of-theinter natio nalhealt h-regul ation s-(2005)-emerg ency-commi ttee-regar ding-the-outbreak-of-novel -coron aviru s-(2019-ncov). Accessed March 30, 2020.

2. Centers for Disease Control and Prevention. (2020). Guidance for Dental Settings. Available from: https://www.cdc.gov/coronavirus/2019ncov/hcp/dental-settings.html. [Accessed on May 05, 2020]. 
3. Mallineni, S.K., Innes, N.P., Raggio, D.P., Araujo, M.P., Robertson, M.D., Jayaraman, J. (2020). Coronavirus disease (COVID- 19): characteristics in children and considerations for dentists providing their care. Int J Paediatr Dent, 30:24550.

4. Khader, Y., Al Nsour, M., Al-Batayneh, O. B., Saadeh, R., Bashier, H., Alfaqih, M., \& Al-Azzam, S. (2020). Dentists' awareness, perception, and attitude regarding COVID-19 and infection control: cross-sectional study among Jordanian dentists. JMIR Public Health and Surveillance, 6(2), e18798.

5. Zemouri, C., de Soet, H., Crielaard, W., \& Laheij, A. (2017). A scoping review on bio-aerosols in healthcare and the dental environment. PloS one, 12(5), e0178007.

6. Ferrazzano, G. F., Ingenito, A., \& Cantile, T. (2020). COVID-19 Disease in Children: What Dentists Should Know and Do to Prevent Viral Spread. The Italian Point of View. International Journal of Environmental Research and Public Health, 17(10), 3642.

7. Meng, L., Hua, F., \& Bian, Z. (2020). Coronavirus disease 2019 (COVID-19): emerging and future challenges for dental and oral medicine. Journal of Dental Research, 99(5), 481-487.

8. Kampf, G., Todt, D., Pfaender, S., \& Steinmann, E. (2020). Persistence of coronaviruses on inanimate surfaces and their inactivation with biocidal agents. Journal of Hospital Infection, 104(3), 246251.

9. Amorim, L. M. D., Maske, T. T., Ferreira, S. H., Santos, R. B. D., Feldens, C. A., \& Kramer, P. F. (2020). New Post-COVID-19 Biosafety Protocols in Pediatric Dentistry. Pesquisa Brasileira em Odontopediatria e Clínica Integrada, 20.

10. Ather, A., Patel, B., Ruparel, N. B., Diogenes, A., \& Hargreaves, K. M. (2020). Coronavirus disease 19 (COVID-19): implications for clinical dental care. Journal of endodontics.

11. American Academy of Pediatric Dentistry. (2020). Re-emergence pediatric dentistry practice checklist. Available from: https://www.aapd.org/globalassets/media/covid19/aapd-practicechecklist.pdf. [Accessed on May 05, 2020]

12. Al-Nerabiah, Z., Alkhouli, M., Laflouf, M., \& Abdul-Hak, M. Pediatric dentists consideration for Covid-19 in children.

13. Estai, M., Kanagasingam, Y., Mehdizadeh, M., Vignarajan, J., Norman, R., Huang, B., \& Tennant, M. (2020). Teledentistry as a novel pathway to improve dental health in school children: a research protocol for a randomised controlled trial. $B M C$ oral health, 20(1), 1-9. 